\title{
Music in DNA: From Williams Syndrome to Musical Genes
}

\author{
Corrada Di Rosa, Filippo Cieri, Ivana Antonucci, Liborio Stuppia, Valentina Gatta* \\ Department of Psychological, Humanities and Territorial Sciences, School of Medicine and Life Sciences, \\ G. d'Annunzio University Chieti-Pescara, Chieti, Italy \\ Email: c.dirosa@hotmail.it, filippocieri@gmail.com, i.antonucci@unich.it, stuppia@unich.it,
}

Received 3 March 2015; accepted 18 March 2015; published 20 March 2015

Copyright (C) 2015 by authors and Scientific Research Publishing Inc.

This work is licensed under the Creative Commons Attribution International License (CC BY). http://creativecommons.org/licenses/by/4.0/

(c) $\underset{\mathrm{EY}}{\mathrm{i}}$ Open Access

\begin{abstract}
Williams syndrome (WS) is a genetic disorder caused by a heterozygous contiguous gene deletion on chromosome 7q11.23. Clinical features of the disease include low IQ and deficit in some cognitive domains, and the presence of relatively strong abilities in social drive, face processing, language, and musical skills. The presence of a strong predisposition to the development of musicality in individuals affected by WS leads us to suppose that some genes deleted in this syndrome are somehow involved in the evolution of this ability, and that these genes could act in normal conditions as "suppressors of music ability". To test this hypothesis, we carried out an "in silico" analysis by using the Ingenuity Pathway Analysis (IPA) software to identify the interaction between genes mapped in the WS critical region and genes previously related to musical ability by literature data. This approach allowed us to identify 3 networks of interaction, involving AVPR1A, NCF1, UNC5C and LAT2 in the first network, STX1A and SLC6A4 in the second one and only WS related genes in the last one. Among these associations, the one involving STX1A and SLC6A4 suggested a possible mechanism of interaction was based on the influence played by STX1A deletion on the serotonin levels through a decrease of SLC6A4 activity.
\end{abstract}

\section{Keywords}

Williams Syndrome, Music Ability, Serotonin

\section{Introduction}

Music is one of the most mysterious aspects of human nature (Charles Darwin-The Origin of Species; 1859).

Music represents a universally diffused practice, endowed of ubiquity in time and culture. For this reason, it

"Corresponding author.

How to cite this paper: Di Rosa, C., Cieri, F., Antonucci, I., Stuppia, L. and Gatta, V. (2015) Music in DNA: From Williams Syndrome to Musical Genes. Open Journal of Genetics, 5, 12-26. http://dx.doi.org/10.4236/ojgen.2015.51002 
comes immediate to wonder which function music has in people's life. Some authors attribute the importance of music to social factors, as cohesion and group cooperation [1]; others consider music as a valid tool to express feelings, being able to arouse deep and meaningful emotions [2]. Darwin proposed in 1871 that singing was used to attract the opposite sex [3]. Furthermore, music provides a tool to study numerous aspects of neuroscience from motor-skill learning to emotion [4].

Despite naturalness and diffusion of music, musical executive competence is characterized by strong differences among individuals, which can be located on a continuum where it is possible to find competences ranging from very scarce to excellent with the majority of people located in the middle with modest production skills. The existence of individual differences in musical competence has driven the interest of researchers to clarify the basis of this variability, especially as concerning the different role played by biological and experiential factors. A biological basis in the development of music ability is supported by the existence of specific behavioural features, like absolute pitch (AP) and congenital amusia, for which a genetic influence has clearly been individualized [5]-[7]. AP is the ability to identify or produce isolated musical tones [8]. This condition can be considered as a complex trait, depending on both genetic factors and exposure to musical training during childhood [5]. On the other hand, congenital amusia, also known as "tone-deafness", is a deficit of music perception that, in absence of deafness or any other cognitive disorder, determines the inability to correctly reproduce sounds. The hereditary component of the congenital amusia has been demonstrated within 9 amusic families, where 39\% of first-degree relatives had the same disorder, against 3\% only in control families [9].

A very peculiar condition strongly suggesting the presence of genes related to the individual musical ability is represented by the great musical abilities existing in individuals affected by Williams syndrome (WS). WS (OMIM 194050) is a multisystem genomic disorder affecting 1/7500 -1/10,000 live births caused by a heterozygous contiguous gene deletion on chromosome 7q11.23 [10]. The common deletion region ranges in size from 1.5 to $1.8 \mathrm{Mb}$ between the polymorphic markers D7S1816 and D7S489B and encompasses approximately 28 genes, including Elastin (ELN), LIM1 kinase (LIMK1), Frizzled (FZD9, previously called FZD3), and Syntaxin1A (STX1A) [11] [12]. A clear genotype-phenotype correlation has been established in WS only for the ELN gene, which is responsible for the vascular and connective tissue abnormalities [13].

Individuals with WS are characterized by low IQ, ranging from 40 to 100 (mean $=61, \mathrm{SD}=11$ ), and deficit in some cognitive domains including conceptual reasoning, problem solving, and spatial cognition [14]. However, the most interesting aspect of WS cognitive profile is the presence of relatively strong abilities in four specific domains: social drive [15], face processing, language [16], and musical skills [17] [18]. Individuals with WS show unique communication strengths and impairments that are challenging to treat in community, educational, and vocational settings. Many issues regarding characteristics of auditory sensitivity in WS remain to be resolved [19].

Studies about this rare syndrome have suggested various candidate genes for the intellectual disability, like GTF2I [20]. Since WS has a clearly defined genetic etiology, playing for sure a role in the determination of the characteristic cognitive and behavioral profile, investigators have used this syndrome as a model to elucidate gene-brain-behavior relationships [21]-[24]. In this view, the existence of a strong predisposition to the development of musicality in individuals affected by WS leads us to suppose that some genes deleted in this syndrome are somehow involved in the evolution of this ability. The general hypothesis of this study is that genes deleted in WS act in normal conditions, in healthy people, as "suppressors of music ability". Assuming this hypothesis is correct, the consequence should be that musical behaviour is expressed naturally and at a superior level in individuals where these genes are inactive.

To verify this hypothesis, we carried out a study to identify the interaction between genes mapped in the WS critical region and genes previously related to musical ability by literature data.

\section{Methods}

The present study has been organized in three steps. In the first part of the study, we analyzed the functions played by genes mapped within the WS critical region in order to verify their possible roles in the development of musical competence. To this aim, we carried out a review of the most recent literature by means of Pubmed, using "William syndrome" "genes" "critical region” and "deletion” as key words.

In the second step of the study, we performed a search of literature data in order to identify other genes, outside the WS critical region, which have been previously suggested as involved in the development of musical 
ability. Also in this case a literature review was carried out by Pubmed, using "genes" and "music" as specific key words.

Finally, we carried out an "in silico" analysis in order to highlight the presence of functional correlation among genes mapped in the critical region for the WS and those evidenced in literature as involved in musical competences. For this part of the study, we used the Ingenuity Pathways Analysis (IPA) software, allowing classifying genes detected in the first two steps of the study on the basis of their biological functions and detecting the functional networks connecting genes among them.

\section{Results}

\subsection{Genes Mapped within WS Critical Region}

Literature data evidence that the following genes are removed by the deletion on 7q11.23: ELN, LIMK1, GTF2I, STX1A, BAZ1A, CYLN2, GTF2IRD1, NCF1, RFC2, FZD9, FKBP6, TBL2, BCL7B, CLDN4, EIF4H, LAT2, WBSCR11, STAG3L, PMS2L, GATS-L, WBSCR19, GTF2IRD2, POM121, NSUN5, TRIM50, FKBP6, FZD9, BAZ1B, BCL7B, TBL2, MLXIPL, VPS37D, DNAJC30, WBSCR22, WBSCR26, ABHD11, CLDN3 and CLDN4, EIF4H, LAT2, RFC2, CLIP2, WBSCR23.

Although no one of these genes has been so far suggested as a candidate for musical abilities, all these genes are expressed in the nervous system, and thus all of them have been considered in the present study as potentially involved in the regulation of other genes mapped outside the WS critical region and directly affecting the development of musical abilities.

Furthermore, some evidences have argued that a haploinsufficiency of the ELN gene may also be involved in the peripheral impairments mediating hyperacusis. Since the elastase enzyme destroys the stereocilia tip links [25], a deficiency of this protein could lead to a desynchronized movement of the stereocilia, resulting in hearing loss and delayed cochlear nerve activation [26]. This would, in turn, adversely affect the acoustic reflex and lead to hyperacusis [27].

\subsection{Genes Connected with Musical Abilities}

A few studies have been performed about genetic component in musical skills.

Considering the possibility that music was an innate ability, Pulli et al. [28] investigated biological basis of music perception, using statistical and molecular genetic approaches and behavioural tests, through 15 Finnish multigenerational families (in total 234 family members). Linkage analyses showed a significant evidence in 4q22 with an interesting candidate gene, namely UNC5C, Netrin receptor. UNC5C interacts with netrins in axon guidance and neuronal migration during central nervous system development. Netrins are essential for inner ear semicircular duct formation, suggesting a role in development of structural-musical ability. Furthermore, netrins appear some way related with ROBO1, candidate gene for dyslexia [29], suggesting a possible common molecular background between musical and linguistic abilities.

One more candidate gene that appears to play a role in "structural-musical abilities" is TRPA1, a member of the transient receptor potential (TRP) family of ion channels, mainly expressed by cells of the inner ear [30]. This gene is located on chromosome 8q12 - 8q13, very close to the region involved in AP.

Unlike UNC5C and TRPA1, related to physical and structural characteristics that "allow to listen the music", other two polymorphic genes have been directly associated to social aspects of musical abilities: the arginine vasopressin 1a receptor (AVPR1a) and the serotonin transporter (SLC6A4) related by literature to several social, emotional and behavioral traits, including musical abilities, musical aptitude and musical memories [31] [32].

AVPR1a gene has been shown to affect many emotional and social traits. Microsatellite repeat regions (RS1 and RS3) located in the human AVPR1a gene promoter have been associated with autism spectrum disorders [33]-[35], prepulse inhibition [36], altruism in a dictator game [37], pair bonding and aggression in males [38] [39], parenting [40] and love [41].

SLC6A4 promoter region polymorphism (5-HTTLPR) is one of the most important genes in emotion regulation and social cognition. It contains a regulatory variation (Short Variant, S, and Long Variant, L) that have been associated with anxiety-related traits and susceptibility for depression [42]. Furthermore, the long 5-HTTLPR allele has two variants (i.e., LA and LG). In the first of two extra 20 - 23 bp repeats in the L allele, a common single nucleotide polymorphism occurs at the sixth nucleotide (adenine to guanine; A to G) [43]. The LG 
variant and the S allele appear to be very similar in terms of transcriptional activity; therefore, only the LA variant is high expressing with regard to transcriptional activity [44].

AVPR1A and SLC6A4 have been directly correlated both to social cognition and musical abilities in different studies. Bachner-Melman et al. [31], in their interesting research, have shown that the AVPR1a in association with the SLC6A4 seems to affect individual's aptitude, propensity, and need for dancing, which is integrally related to music. The authors had examined performing dancers, elite athletes, and nonathletes/nondancers observing significant differences in allele frequencies for both genes when dancers were compared to athletes as well as to nondancers/nonathletes. Furthermore, these two genes were also associated with scores on the Tellegen Absorption Scale (a questionnaire that correlates positively with spirituality and altered states of consciousness since spirituality personality facets important in the dance phenotype) and Reward Dependence (measure aspects of social communication) of Tridimensional Personality Questionnaire, suggesting that the association between these genes and dance is mediated by personality factors reflecting the social communication of the dancing phenotype [31].

In order to investigate genetic contribution of musical abilities, Granot et al. [32] analyzed the relation between AVPR1a and SLC6A4 and music memory using a specific battery MBEA (Montreal Battery of Evaluation of Amusia) and genetic analyses for involved regions. Results showed that polymorphisms related to AVPR1a and SLC6A4 were associated with short term memory for music although they were not specific for music processing.

Moreover, Donaldson et al. [45] argued that association with the AVPR1A receptor gene that mediated the effects of highly conserved AVP suggested that listening to music was related to the pathways affecting attachment behaviour and social communication. In fact, several behavioural features in listening (perceiving) music are closely related to attachment: Lullabies are song to infants to increase their attachment to a parent, and singing or playing music together may add group cohesion [9]. Thus lullabies could be one example of important environmental factor that can interact with other factors (genetics, biological and socio-cultural) in order to develop some social features as attachment and/or musicality disposition or sensitivity.

\subsection{Correlation between Deleted Genes in WS and Musical Genes}

Results of the second step of our study evidenced four candidate genes for musical abilities: (UNC5C, TRP1A, AVPR1a and SLC6A4), all considered in the third step of our investigation, aimed to explore the presence of a relation between genes related to music by literature data and deleted genes in WS.

\subsection{IPA Functional Analysis of Genes Related to Williams Syndrome and Musical Abilities Genes}

After the identification of genes selectively involved to Williams syndrome and musical abilities, we employed Ingenuity Pathway Analysis (IPA) to further investigate key biological functions and networks linked to these genes. IPA analysis revealed that the main functions involved were: Cardiovascular Disease, Developmental Disorder, Endocrine System Disorders, Hereditary Disorder, Organismal Injury and Abnormalities, Renal and Urological Disease, Behavior showing a p-value ranging from 1.91E-08 to 4.45E-02 (Table 1). The identified functions are displayed as bar chart in Figure 1. Among these, some genes enclosed within behavior class function are specifically related to the formation of neural circuits and could mediate WS musical abilities.

\subsection{Networks Associated with Genes Related to Williams Syndrome and Musical Abilities Genes}

We employed IPA to study how the selected genes were interacting in specific networks. IPA predicts functional networks based on known protein-protein and functional interactions. IPA infers and ranks networks by a score, expressed as a numerical value, which is a probabilistic fit between the amount of focus genes that are potentially eligible for a network composition and present on a given gene list, the size of the network, as well as all the molecules present in the Ingenuity Knowledge Base that can be part of such a network.

IPA analysis of the selected genes generated 3 networks with a score of 27, 24 and 21.

In the first top network (Figure 2, Table 2), we found ten WS related genes (ABHD11, CLIP2, EIF4H, LAT2, NSUN5, M121/POM121C, TBL2, TRIM50, VPS37D, WBSCR27) and two musical abilities genes (TRPA1, 
Table 1. Main functions played by WS genes.

\begin{tabular}{crr}
\hline Cardiovascular Disease & $1.91 \mathrm{E}-08-4.11 \mathrm{E}-02$ & ELN, MLXIPL, NCF1, EIF4H, SLC6A4, BAZ1B, LIMK1 \\
Developmental Disorder & $1.91 \mathrm{E}-08-4.11 \mathrm{E}-02$ & ELN, MLXIPL, NCF1, PMS2, SLC6A4, LIMK1 \\
Endocrine System Disorders & $1.91 \mathrm{E}-08-4.45 \mathrm{E}-02$ & ELN, MLXIPL, PMS2, BAZ1B, CLDN3, LIMK1 \\
Hereditary Disorder & $1.91 \mathrm{E}-08-3.77 \mathrm{E}-02$ & ELN, MLXIPL, NCF1, SLC6A4, PMS2, AVPR1A, LIMK1 \\
Organismal Injury and Abnormalities & $1.91 \mathrm{E}-08-4.11 \mathrm{E}-02$ & ELN, NCF1, MLXIPL, LAT2, PMS2, TRPA1, SLC6A4, LIMK1 \\
Renal and Urological Disease & $1.91 \mathrm{E}-08-1.9 \mathrm{E}-02$ & ELN, MLXIPL, SLC6A4, LIMK1 \\
Behavior & $1.16 \mathrm{E}-06-4.45 \mathrm{E}-02$ & NCF1, SLC6A4, TRPA1, FZD9, STX1A, GTF2IRD1, AVPR1A, LIMK1 \\
\hline
\end{tabular}

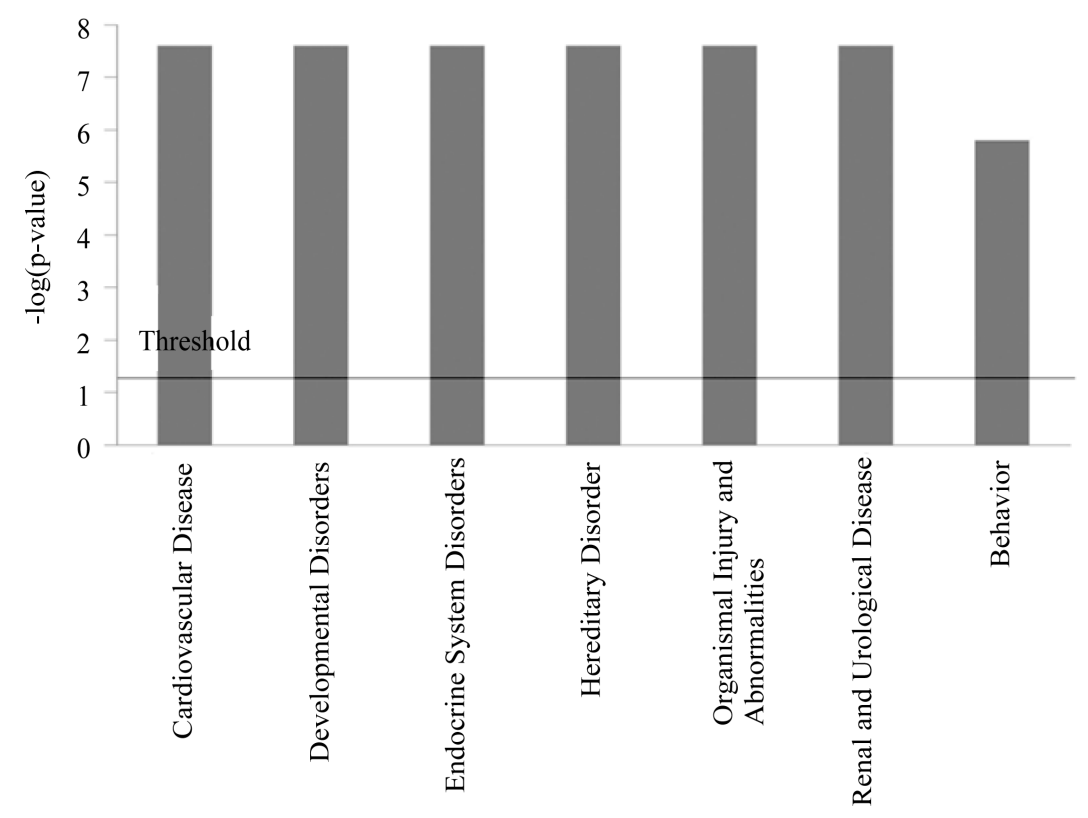

Figure 1. Bar chart showing the main functions played by WS and musical abilities related genes. The high-level functional categories that are involved in this analysis are displayed along the $\mathrm{x}$-axis. The $\mathrm{y}$-axis displays the -log significance. Taller bars are more significant than shorter bars. Functions are listed from most significant to least and the orange horizontal line denotes the cutoff for significance ( $p$-value of 0.05).

UNC5C). The analysis of this network evidenced an indirect relationship among Williams and music related genes (AVPR1A to NCF1 and UNC5C to LAT2) but, as mentioned, these were non significant for our purpose.

The second network (Figure 3, Table 3) is composed by 9 Williams related genes (ELN, FZD9, GTF2I, GTF2IRD1, NCF1, PMS2, RFC2, STAG3, STX1A) and two musical abilities genes (SLC6A4, AVPR1A).

Interestingly, as depicted, we observed a direct correlation between STX1A and SLC6A4 (5-HTT), a Williams and music related genes, respectively. This direct correlation is supported by four Source Ingenuity Expert Findings [46]-[49] and can suggest a role of STX1A in development of musical abilities.

The third network includes only ten Williams related genes (BAZ1B, BCL7B, CLDN3, CLDN4, DNAJC30, FKBP6, GTF2IRD2, LIMK1, MLXIPL, WBSCR22) and no music related genes, and it doesn't reveal any interesting gene-gene relationship (Figure 4, Table 4).

\subsection{Functional Correlation between STX1A and SLC6A4}

SLC6A4, the serotonin transporter gene, is involved in the formation of neural circuits. Factors regulating the expression of serotonin transporter could have a role in cortical development. Syntaxin 1A (STX1A) can be one 


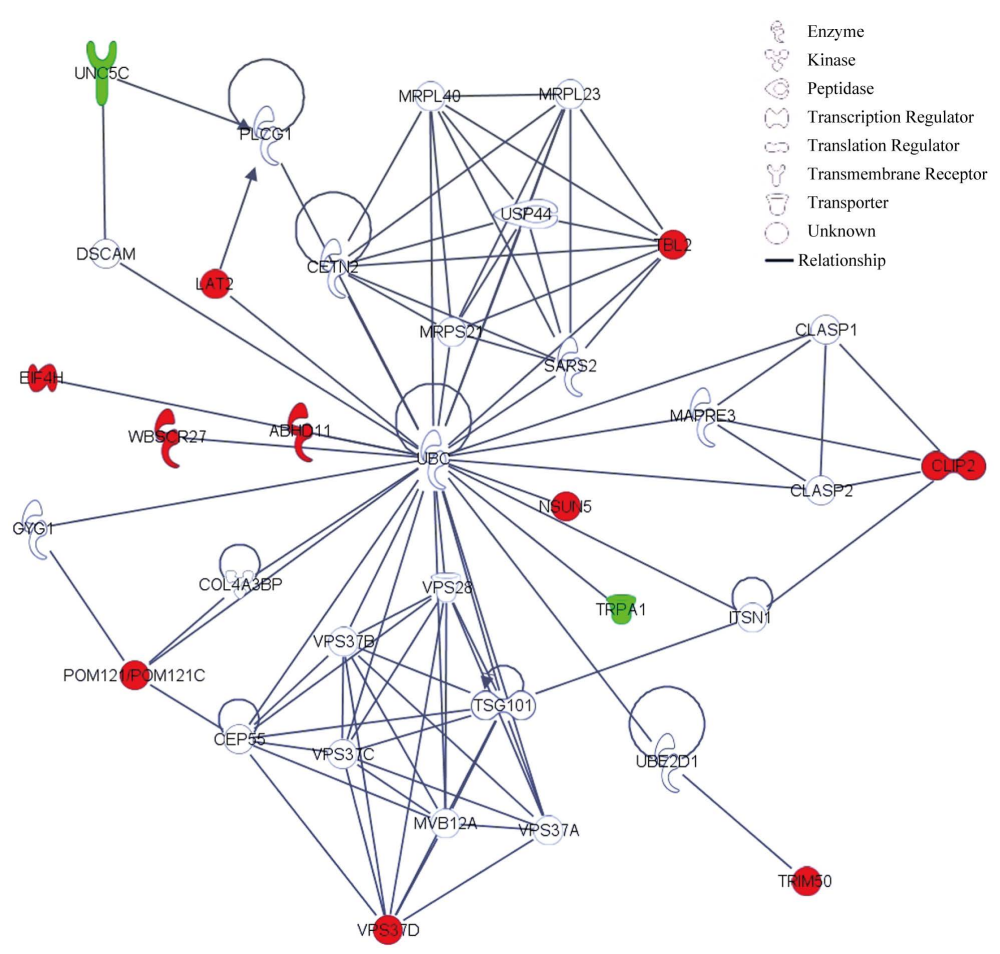

Figure 2. First top network generated by IPA showing indirect interactions between WS and music related genes. Gray indicates WS related genes; light gray indicates music related genes. Genes inferred by IPA are represented in white. Arrows indicate that a molecule acts on another while lines indicate that a molecule binds to another.

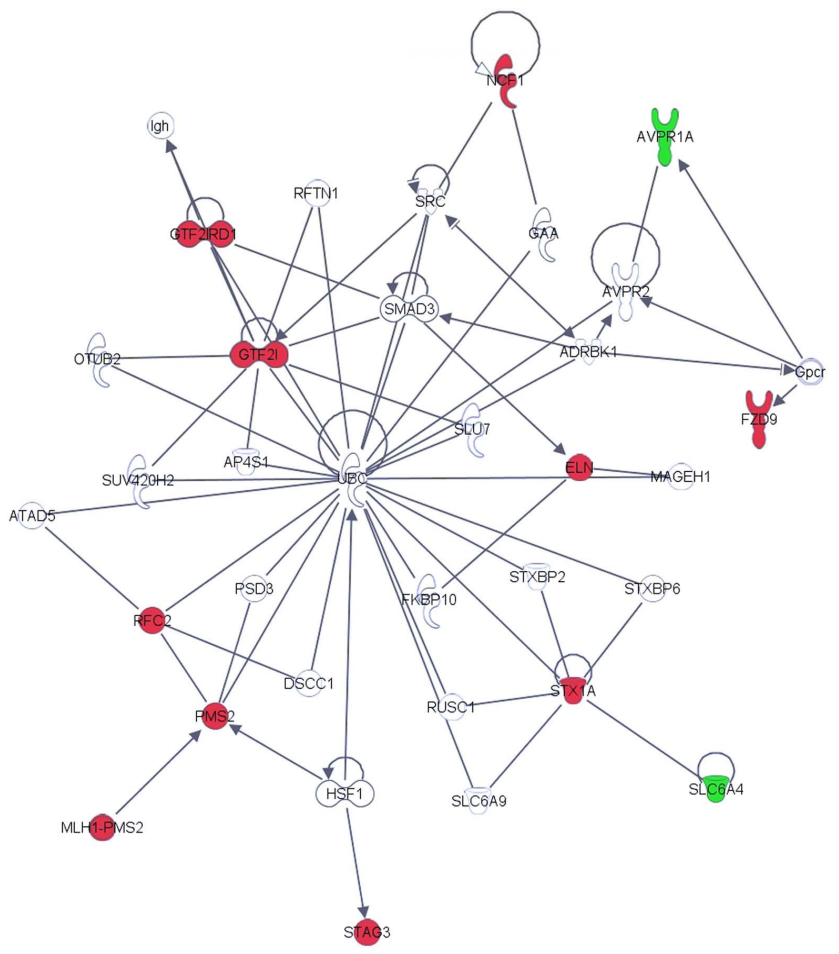

Figure 3. Second top network generated by IPA showing direct and indirect interactions between WS and music related genes. The network shows the direct interaction between STX1A and SLC6A4 genes. Gray indicates WS related genes; light gray indicates music related genes. Genes inferred by IPA are represented in white. Arrows indicate that a molecule acts on another while lines indicate that a molecule binds to another. 
Table 2. Genes involved in the network 1. In bold genes associated to WS or musical abilities.

\begin{tabular}{|c|c|c|c|}
\hline Symbol & Entrez Gene Name & Entrez Gene & Location \\
\hline ABHD11 & abhydrolase domain containing 11 & 83451 & Cytoplasm \\
\hline CEP55 & centrosomal protein $55 \mathrm{kDa}$ & & Cytoplasm \\
\hline CETN2 & centrin, EF-hand protein, 2 & & Nucleus \\
\hline CLASP1 & cytoplasmic linker associated protein 1 & & Cytoplasm \\
\hline CLASP2 & cytoplasmic linker associated protein 2 & & Cytoplasm \\
\hline CLIP2 & CAP-GLY domain containing linker protein 2 & 7461 & Cytoplasm \\
\hline COL4A3BP & collagen, type IV, alpha 3 (Goodpasture antigen) binding protein & & Cytoplasm \\
\hline DSCAM & Down syndrome cell adhesion molecule & & Plasma Membrane \\
\hline EIF4H & eukaryotic translation initiation factor $4 \mathrm{H}$ & 7458 & Cytoplasm \\
\hline GYG1 & glycogenin 1 & & Cytoplasm \\
\hline ITSN1 & intersectin 1 (SH3 domain protein) & & Cytoplasm \\
\hline LAT2 & linker for activation of $\mathrm{T}$ cells family, member 2 & 7462 & Plasma Membrane \\
\hline MAPRE3 & microtubule-associated protein, RP/EB family, member 3 & & Cytoplasm \\
\hline MRPL23 & mitochondrial ribosomal protein L23 & & Cytoplasm \\
\hline MRPL40 & mitochondrial ribosomal protein L40 & & Cytoplasm \\
\hline MRPS21 & mitochondrial ribosomal protein S21 & & Cytoplasm \\
\hline MVB12A & multivesicular body subunit $12 \mathrm{~A}$ & & Cytoplasm \\
\hline NSUN5 & NOP2/Sun domain family, member 5 & 55695 & Unknown \\
\hline PLCG1 & phospholipase C, gamma 1 & & Cytoplasm \\
\hline POM121/POM121C & POM121 transmembranenucleoporin & 9883 & Nucleus \\
\hline SARS2 & seryl-tRNAsynthetase 2, mitochondrial & & Cytoplasm \\
\hline TBL2 & transducin (beta)-like 2 & 26608 & Plasma Membrane \\
\hline TRIM50 & tripartite motif containing 50 & 135892 & Unknown \\
\hline TRPA1 & transient receptor potential cation channel, subfamily A, member 1 & 8989 & Plasma Membrane \\
\hline TSG101 & tumor susceptibility gene 101 & & Cytoplasm \\
\hline UBC & ubiquitin C & & Cytoplasm \\
\hline UBE2D1 & ubiquitin-conjugating enzyme E2D 1 & & Cytoplasm \\
\hline UNC5C & unc-5 homolog C (C. elegans) & 8633 & Plasma Membrane \\
\hline USP44 & ubiquitin specific peptidase 44 & & Nucleus \\
\hline VPS28 & vacuolar protein sorting 28 homolog (S. cerevisiae) & & Cytoplasm \\
\hline VPS37A & vacuolar protein sorting 37 homolog A (S. cerevisiae) & & Cytoplasm \\
\hline VPS37B & vacuolar protein sorting 37 homolog B (S. cerevisiae) & & Cytoplasm \\
\hline VPS37C & vacuolar protein sorting 37 homolog C (S. cerevisiae) & & Cytoplasm \\
\hline VPS37D & vacuolar protein sorting 37 homolog D (S. cerevisiae) & 155382 & Cytoplasm \\
\hline WBSCR27 & Williams Beuren syndrome chromosome region 27 & 155368 & Unknown \\
\hline
\end{tabular}


Table 3. Genes involved in the network 2. In bold genes associated to WS or musical abilities.

\begin{tabular}{|c|c|c|c|}
\hline Symbol & Entrez Gene Name & Entrez Gene & Location \\
\hline ADRBK1 & adrenergic, beta, receptor kinase 1 & & Cytoplasm \\
\hline AP4S1 & adaptor-related protein complex 4 , sigma 1 subunit & & Cytoplasm \\
\hline ATAD5 & ATPase family, AAA domain containing 5 & & Extracellular Space \\
\hline AVPR1A & arginine vasopressin receptor $1 \mathrm{~A}$ & 552 & Plasma Membrane \\
\hline AVPR2 & arginine vasopressin receptor 2 & & Plasma Membrane \\
\hline DSCC1 & defective in sister chromatid cohesion 1 homolog (S. cerevisiae) & & Nucleus \\
\hline ELN & elastin & 2006 & Extracellular Space \\
\hline FKBP10 & FK506 binding protein $10,65 \mathrm{kDa}$ & & Cytoplasm \\
\hline FZD9 & frizzled family receptor 9 & 8326 & Plasma Membrane \\
\hline GAA & glucosidase, alpha; acid & & Cytoplasm \\
\hline Gpcr & & & Unknown \\
\hline GTF2I & general transcription factor IIi & 2969 & Nucleus \\
\hline GTF2IRD1 & GTF2I repeat domain containing 1 & 9569 & Nucleus \\
\hline HSF1 & heat shock transcription factor 1 & & Nucleus \\
\hline Igh & immunoglobulin heavy chain complex & & Unknown \\
\hline MAGEH1 & melanoma antigen family $\mathrm{H}, 1$ & & Cytoplasm \\
\hline MLH1-PMS2 & & & Nucleus \\
\hline NCF1 & neutrophil cytosolic factor 1 & 653361 & Cytoplasm \\
\hline OTUB2 & OTU domain, ubiquitin aldehyde binding 2 & & Unknown \\
\hline PMS2 & PMS2 postmeiotic segregation increased 2 (S. cerevisiae) & 5395 & Nucleus \\
\hline PSD3 & pleckstrin and Sec7 domain containing 3 & & Cytoplasm \\
\hline RFC2 & replication factor C (activator 1 ) 2, $40 \mathrm{kDa}$ & 5982 & Nucleus \\
\hline RFTN1 & raftlin, lipid raft linker 1 & & Plasma Membrane \\
\hline RUSC1 & RUN and SH3 domain containing 1 & & Cytoplasm \\
\hline SLC6A4 & solute carrier family 6 (neurotransmitter transporter, serotonin), member 4 & 6532 & Plasma Membrane \\
\hline SLC6A9 & solute carrier family 6 (neurotransmitter transporter, glycine), member 9 & & Plasma Membrane \\
\hline SLU7 & SLU7 splicing factor homolog (S. cerevisiae) & & Nucleus \\
\hline SMAD3 & SMAD family member 3 & & Nucleus \\
\hline SRC & v-src sarcoma (Schmidt-Ruppin A-2) viral oncogene homolog (avian) & & Cytoplasm \\
\hline STAG3 & stromal antigen 3 & 10734 & Nucleus \\
\hline STX1A & syntaxin $1 \mathrm{~A}$ (brain) & 6804 & Cytoplasm \\
\hline STXBP2 & syntaxin binding protein 2 & & Plasma Membrane \\
\hline STXBP6 & syntaxin binding protein 6 (amisyn) & & Cytoplasm \\
\hline SUV420H2 & suppressor of variegation 4-20 homolog 2 (Drosophila) & & Nucleus \\
\hline UBC & ubiquitin C & & Cytoplasm \\
\hline
\end{tabular}


Table 4. Genes involved in the network 3. In bold genes associated to WS.

\begin{tabular}{|c|c|c|c|}
\hline Symbol & Entrez Gene Name & Entrez Gene & Location \\
\hline ACACB & acetyl-CoA carboxylase beta & & Cytoplasm \\
\hline ACLY & ATP citrate lyase & & Cytoplasm \\
\hline ATAD5 & ATPase family, AAA domain containing 5 & & Extracellular Space \\
\hline BAZ1A & bromodomain adjacent to zinc finger domain, $1 \mathrm{~A}$ & & Nucleus \\
\hline BAZ1B & bromodomain adjacent to zinc finger domain, $1 \mathrm{~B}$ & 9031 & Nucleus \\
\hline BAZ2A & bromodomain adjacent to zinc finger domain, $2 \mathrm{~A}$ & & Nucleus \\
\hline BCL7A & B-cell CLL/lymphoma 7A & & Unknown \\
\hline BCL7B & B-cell CLL/lymphoma 7B & 9275 & Unknown \\
\hline CDC42BPA & CDC42 binding protein kinase alpha (DMPK-like) & & Cytoplasm \\
\hline Cldn & & & Plasma Membrane \\
\hline CLDN1 & claudin 1 & & Plasma Membrane \\
\hline CLDN3 & claudin 3 & 1365 & Plasma Membrane \\
\hline CLDN4 & claudin 4 & 1364 & Plasma Membrane \\
\hline CLDN5 & claudin 5 & & Plasma Membrane \\
\hline CLDN8 & claudin 8 & & Plasma Membrane \\
\hline DNAJC30 & DnaJ (Hsp40) homolog, subfamily C, member 30 & 84277 & Cytoplasm \\
\hline ELAVL1 & $\begin{array}{l}\text { ELAV (embryonic lethal, abnormal vision, Drosophila)-like } 1 \\
\text { (Hu antigen R) }\end{array}$ & & Cytoplasm \\
\hline FGF21 & fibroblast growth factor 21 & & Extracellular Space \\
\hline FKBP6 & FK506 binding protein $6,36 \mathrm{kDa}$ & 8468 & Nucleus \\
\hline GTF2IRD2 & GTF2I repeat domain containing 2 & 84163 & Unknown \\
\hline HNF4A & hepatocyte nuclear factor 4, alpha & & Nucleus \\
\hline LIMK1 & LIM domain kinase 1 & 3984 & Cytoplasm \\
\hline MID1IP1 & MID1 interacting protein 1 & & Cytoplasm \\
\hline MLXIPL & MLX interacting protein-like & 51085 & Nucleus \\
\hline MYO1A & myosin IA & & Cytoplasm \\
\hline NME7 & NME/NM23 family member 7 & & Cytoplasm \\
\hline PHF10 & PHD finger protein 10 & & Nucleus \\
\hline PHF21A & PHD finger protein 21A & & Nucleus \\
\hline SMARCA4 & $\begin{array}{l}\text { SWI/SNF related, matrix associated, actin dependent regulator } \\
\text { of chromatin, subfamily a, member } 4\end{array}$ & & Nucleus \\
\hline SS18 & synovial sarcoma translocation, chromosome 18 & & Nucleus \\
\hline SUMO2 & SMT3 suppressor of mif two 3 homolog 2 (S. cerevisiae) & & Nucleus \\
\hline TJP1 & tight junction protein 1 & & Plasma Membrane \\
\hline TP53 & tumor protein p53 & & Nucleus \\
\hline VHL & vonHippel-Lindau tumor suppressor, E3 ubiquitin protein ligase & & Nucleus \\
\hline WBSCR22 & Williams Beuren syndrome chromosome region 22 & 114049 & Nucleus \\
\hline
\end{tabular}




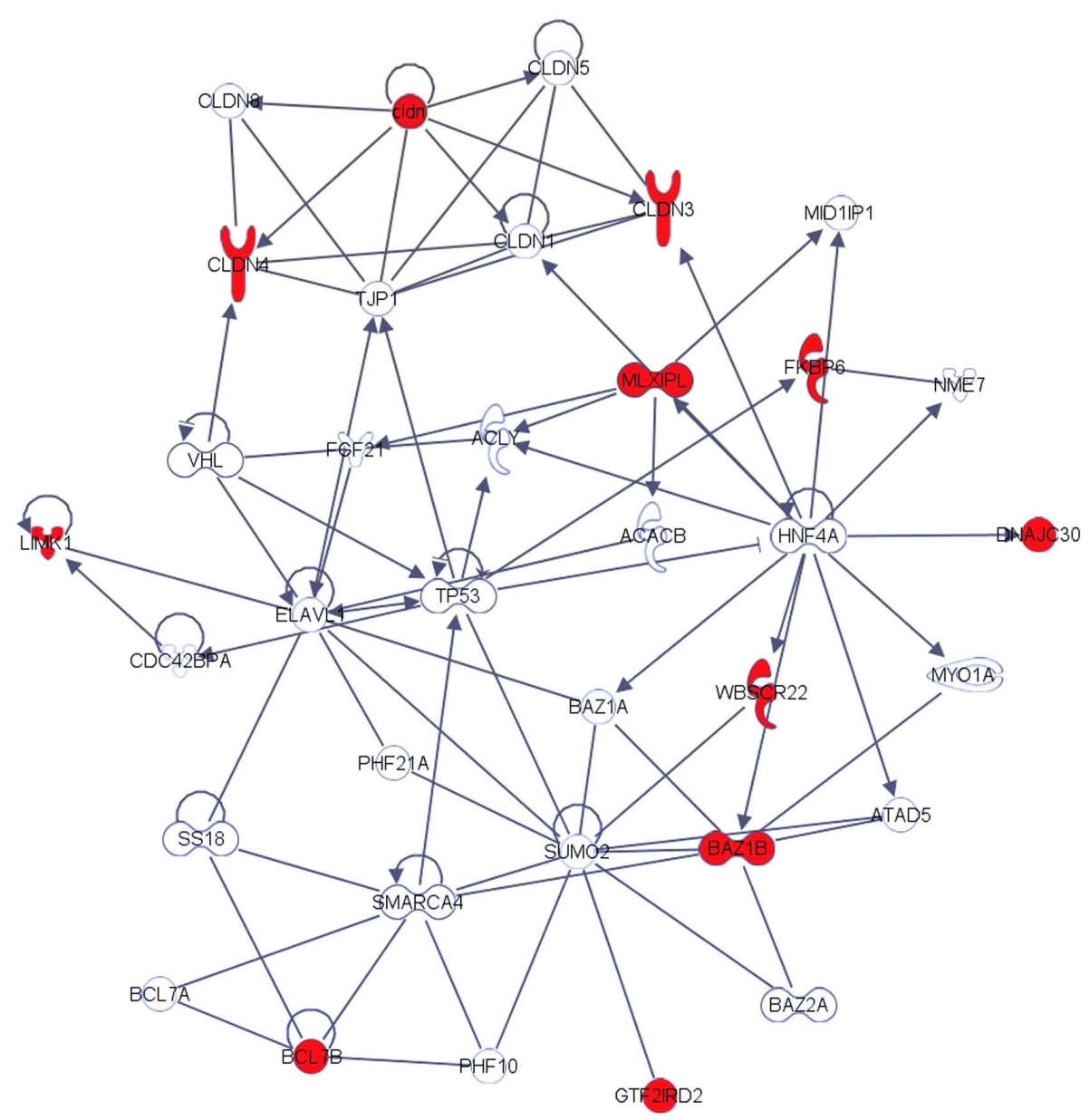

Figure 4. Third top network generated by IPA showing the interactions among WS genes. Gray indicates WS related genes. Genes inferred by IPA are represented in white. Arrows indicate that a molecule acts on another while lines indicate that a molecule binds to another.

of these factors, being involved in synaptic transmission. Particularly, a physic interaction between SERT and STX1A could be responsible for modulation of serotonin reuptake. SERT function is reduced by the deletion of STX1A in WS, suggesting a different development of specific cognitive skills such as music abilities.

\section{Discussion}

Since 1990, technological development has largely modified our approach to biological and medical information. For instance, genome-wide association studies (GWASs) have revolutionized the field of human quantitative genetics and genome sequencing and gene expression data were used to identify gene modifications and modulations related to specific phenotypes. However, these experimental efforts to measure the functions of genes, especially those of unknown function, which are very challenging and very expensive in terms of time, effort, and money. Nowadays the use of appropriate hardware and software makes it possible to simulate static or dynamic, even complex, physiological or cellular processes to unravel the molecular pathways which are modulated by diverse set of genes in the hope of discovering information that would prompt future studies.

Analysis in silico, made through computer programs, represents an important new research method that allows the examination of a large amount of data not possible in a different way, if not with great human and economical efforts. For this reason we used this method to verify the initial hypothesis of this work, especially using IPA software to verify the possibility that some deleted gene in Williams syndrome acted, in normal conditions, as suppressor of other genes that were able to influence the development of musical skills.

Many studies have investigated genotype-phenotype correlation in WS individuals, but a clear, direct link has 
been established only for the elastin gene (ELN) responsible for the SVAS [50] [51]. Moreover, mouse models have suggested other genotype-phenotype correlations, such as those between craniofacial abnormalities and GTF2I and GTF2IRD1 genes [52], tooth anomalies and visuo-spatial deficit, associated to GTF2I, GTF2IRD1 and GTF2IRD2 genes [53], as well as deficits in motor coordination, associated with CLIP2 gene [54]. Likewise, the function of the carbohydrate response element-binding protein (MLXIPL, a.k.a. ChREBP or WBSCR14) in the regulation of the expression of enzymes involved in glucose and lipid metabolism [55] [56] suggests that haploinsufficiency of this gene is associated with the higher relative body fat, silent diabetes and/or impaired glucose tolerance found in WS adult individuals [57]. The molecular substrates underlying the other clinical features of 7q11.23 CNVs, including the neurocognitive phenotypes, are still debated [58].

For this reason, it can be interesting to consider the observed direct correlation between STX1A and SLC6A4, the serotonin transporter gene. Neocortex receives serotoninergic innervations at the beginning of the development, suggesting an important role of serotonin in the formation of neural circuits [59] [60].

Levels of serotonin during the development influence the neural morphology [61] and density of synaptic contacts [62]. Levels of serotonin are important also in modulation of synaptic plasticity [63] [64], neural activity [65] and neural maturation [66]. Experimental manipulation in serotonin levels during the first post-natal development can produce characteristic behavioural syndromes [67] [68] and long term cognitive damages [69][71]. Furthermore, changes in normal serotonergic signalling reveal a crucial role of serotonin system in the formation of sensitive maps of somatosensorial [72] [73] and visual [74] [75] systems. Then, SERT regulation in neocortex 5HT levels can have serious physiological, anatomical and behavioural effects. Reduction of STX1A results in decreased function and expression of SERT. Reduction of STX1A is related to a decrease of SERT function. STX1A acts like a positive regulator of synaptic signalling [48].

\section{Conclusions}

Since in normal conditions, STX1A influence serotonin levels, the results of research suggest that the lack of STX1A could cause alterations of 5HT levels justifying a different development of specific cognitive skills.

Specific cognitive abilities are involved in listening, processing and producing music, so musicality can be considered as a particular form of cognitive profile.

For this reason, it cannot be excluded the involvement of serotonin not only in the development of basic cognitive abilities but also in musical abilities.

\section{References}

[1] Huron, D. (2001) Is Music an Evolutionary Adaptation? Annals of the New York Academy of Sciences, 930, 43-61. http://dx.doi.org/10.1111/j.1749-6632.2001.tb05724.x

[2] Dowling, W.J. (1986) The Psychology of Music: The Musical Mind. Science, 231, 279-280. http://dx.doi.org/10.1126/science.231.4735.279

[3] Darwin, C. (1871) The Descent of Man, and Selection in Relation to Sex, Volume 1. John Murray, London. http://dx.doi.org/10.1037/12293-000

[4] Zatorre, R. and McGill, J. (2005) Music, the Food of Neuroscience? Nature, 434, 312-315. http://dx.doi.org/10.1038/434312a

[5] Zatorre, R.J. (2003) Music and the Brain. Annals of the New York Academy of Sciences, 999, 4-14. http://dx.doi.org/10.1196/annals.1284.001

[6] Theusch, E., Basu, A. and Gitschier, J. (2009) Genome-Wide Study of Families with Absolute Pitch Reveals Linkage to 8q24.21 and Locus Heterogeneity. The American Journal of Human Genetics, 85, 112-119. http://dx.doi.org/10.1016/j.ajhg.2009.06.010

[7] Theusch, E. and Gitschier, J. (2011) Absolute Pitch Twin Study and Segregation Analysis. Twin Research and Human Genetics, 14, 173-178. http://dx.doi.org/10.1375/twin.14.2.173

[8] Vanzella, P. and Schellenberg, E.G. (2010) Absolute Pitch: Effects of Timbre on Note-Naming Ability. PLoS One, 5, e15449. http://dx.doi.org/10.1371/journal.pone.0015449

[9] Peretz, I., Cummings, S. and Dubé, M.P. (2007) The Genetics of Congenital Amusia (Tone Deafness): A Family-Aggregation Study. The American Journal of Human Genetics, 81, 582-588. http://dx.doi.org/10.1086/521337

[10] Strømme, P., Bjørnstad, P.G. and Ramstad, K. (2002) Prevalence Estimation of Williams Syndrome. Journal of Child Neurology, 17, 269-271. http://dx.doi.org/10.1177/088307380201700406 
[11] Ewart, A.K., Morris, C.A., Atkinson, D., Jin, W., Sternes, K., Spallone, P., Stock, A.D., Leppert, M. and Keating, M.T. (1993) Hemizygosity at the Elastin Locus in a Developmental Disorder, Williams Syndrome. Nature Genetics, 5, 11-16. http://dx.doi.org/10.1038/ng0993-11

[12] Francke, U. (1999) Williams-Beuren Syndrome: Genes and Mechanisms. Human Molecular Genetics, 8, $1947-1954$. http://dx.doi.org/10.1093/hmg/8.10.1947

[13] Micale, L., Turturo, M.G., Fusco, C., Augello, B., Jurado, L.A., Izzi, C., Digilio, M.C., Milani, D., Lapi, E., Zelante, L. and Merla, G. (2010) Identification and Characterization of Seven Novel Mutations of Elastin Gene in a Cohort of Patients Affected by Supravalvular Aortic Stenosis. European Journal of Human Genetics, 18, 317-323. http://dx.doi.org/10.1038/ejhg.2009.181

[14] Bellugi, U., Lichtenberger, L., Mills, D., Galaburda, A. and Korenberg, J.R. (1999) Bridging Cognition, the Brain and Molecular Genetics: Evidence from Williams Syndrome. Trends in Neurosciences, 22, 197-207. http://dx.doi.org/10.1016/S0166-2236(99)01397-1

[15] Gosch, A. and Pankau, R. (1997) Personality Characteristics and Behaviour Problems in Individuals of Different Ages with Williams Syndrome. Developmental Medicine \& Child Neurology, 39, 527-533. http://dx.doi.org/10.1111/j.1469-8749.1997.tb07481.x

[16] Bellugi, U., Korenberg, J.R. and Klima, E.S. (2001) Williams Syndrome: An Exploration of Neurocognitive and Genetic Features. Journal of Clinical Neurosciences Research, 1, 217-229. http://dx.doi.org/10.1016/S1566-2772(01)00008-1

[17] Don, A.J., Schellenberg, E.G. and Rourke, B.P. (1999) Music and Language Skills of Children with Williams Syndrome. Child Neuropsychology, 5, 154-170. http://dx.doi.org/10.1076/chin.5.3.154.7337

[18] Hopyan, T., Dennis, M., Weksberg, R. and Cytrynbaum, C. (2001) Music Skills and the Expressive Interpretation of Music in Children with Williams-Beuren Syndrome: Pitch, Rhythm, Melodic Imagery, Phrasing, and Musical Affect. Child Neuropsychology, 7, 42-53. http://dx.doi.org/10.1076/chin.7.1.42.3147

[19] Marler, J.A., Elfenbein, J.L. and Ryals, B.M. (2005) Sensorineural Hearing Loss in Children and Adults with Williams Syndrome. American Journal of Medical Genetics Part A, 138, 318-327. http://dx.doi.org/10.1002/ajmg.a.30970

[20] Morris, A.C., Mervis, C.B., Hobart, H.H., Gregg, R.G., Bertrand, J., Ensing, G.J., Sommer, A., Moore, C.A., Hopkin, R.J., Spallone, P.A., Keating, M.T., Osborne, L., Kimberley, K.W. and Stock, A.D. (2003) GTF2I Hemizygosity Implicated in Mental Retardation in Williams Syndrome: Genotype-Phenotype Analysis of Five Families with Deletions in the Williams Syndrome Region. American Journal of Medical Genetics Part A, 123A, 45-59. http://dx.doi.org/10.1002/ajmg.a.20496

[21] Cassidy, S.B. and Morris, C.A. (2002) Behavioral Phenotypes in Genetic Syndromes: Genetic Clues to Human Behavior. Advances in Pediatrics, 49, 59-86.

[22] Meyer-Lindenberg, A., Buckholtz, J.W., Kolachana, B., Hariri, A.R., Pezawas, L., Blasi, G., Wabnitz, A., Honea, R., Verchinski, B., Callicott, J.H., Egan, M., Mattay, V. and Weinberger, D.R. (2006) Neural Mechanisms of Genetic Risk for Impulsivity and Violence in Humans. Proceedings of the National Academy of Sciences of the United States of America, 103, 6269-6274. http://dx.doi.org/10.1073/pnas.0511311103

[23] Järvinen-Pasley, A., Bellugi, U., Reilly, J., Mills, D.L., Galaburda, A., Reiss, A.L. and Korenberg, J.R. (2008) Defining the Social Phenotype in Williams Syndrome: A Model for Linking Gene, the Brain, and Behavior. Development and Psychopathology, 20, 1-35. http://dx.doi.org/10.1017/S0954579408000011

[24] Morris, A.C. (2010) Introduction: Williams Syndrome. American Journal of Medical Genetics Part C, Seminars in Medical Genetics, 154, 203-208. http://dx.doi.org/10.1002/ajmg.c.30266

[25] Silman, S. and Gelfand, S.A. (1981) The Relationship between Magnitude of Hearing Loss and Acoustic Reflex Threshold Levels. Journal of Speech and Hearing Disorders, 46, 312-316. http://dx.doi.org/10.1044/jshd.4603.312

[26] Zarchi, O., Attias, J. and Gothelf, D. (2010) Auditory and Visual Processing in Williams Syndrome. The Israel Journal of Psychiatry and Related Sciences, 47, 125-131.

[27] Gothelf, D., Farber, N., Raveh, E., Apter, A. and Attias, J. (2006) Hyperacusis in Williams Syndrome. Characteristics and Associated Neuroaudiologic Abnormalities. Neurology, 66, 390-395. http://dx.doi.org/10.1212/01.wnl.0000196643.35395.5f

[28] Pulli, K., Karma, K., Norio, R., Sistonen, P., Göring, H.H. and Järvelä, I. (2008) Genome-Wide Linkage Scan for Loci of Musical Aptitude in Finnish Families: Evidence for a Major Locus at 4q22. Journal of Medical Genetics, 45, 451-456. http://dx.doi.org/10.1136/jmg.2007.056366

[29] Williams, J. and O’Donovan, M.C. (2006) The Genetics of Developmental Dyslexia. European Journal of Human Genetics, 14, 681-689. http://dx.doi.org/10.1038/sj.ejhg.5201575

[30] Kwan, K.Y., Allchorne, A.J., Vollrath, M.A., Christensen, A.P., Zhang, D.S., Woolf, C.J. and Corey, D.P. (2006) 
TRPA1 Contributes to Cold, Mechanical, and Chemical Nociception but Is Not Essential for Hair-Cell Transduction. Neuron, 50, 277-289. http://dx.doi.org/10.1016/j.neuron.2006.03.042

[31] Bachner-Melman, R., Dina, C., Zohar, A.H., Constantini, N., Lerer, E., Hoch, S., Sella, S., Nemanov, L., Gritsenko, I., Lichtenberg, P., Granot, R. and Ebstein, R.P. (2005) AVPR1a and SLC6A4 Gene Polymorphisms Are Associated with Creative Dance Performance. PLOS Genetics, 1, e42. http://dx.doi.org/10.1371/journal.pgen.0010042

[32] Granot, R.Y., Frankel, Y., Gritsenko, V., Lererd, E., Gritsenkoc, I., Bachner-Melmane, R., Israelb, S. and Ebstein, R.P. (2007) Provisional Evidence That the Arginine Vasopressin 1a Receptor Gene Is Associated with Musical Memory. Evolution and Human Behavior, 28, 313-318. http://dx.doi.org/10.1016/j.evolhumbehav.2007.05.003

[33] Kim, S.J., Young, L.J., Gonen, D., Veenstra-VanderWeele, J., Courchesne, R., Courchesne, E., Lord, C., Leventhal, B.L., Cook Jr., E.H. and Insel, T.R. (2002) Transmission Disequilibrium Testing of Arginine Vasopressin Receptor 1A (AVPR1a) Polymorphisms in Autism. Molecular Psychiatry, 7, 503-507. http://dx.doi.org/10.1038/sj.mp.4001125

[34] Yirmiya, N., Rosenberg, C., Levi, S., Salomon, S., Shulman, C., Nemanov, L., Dina, C. and Ebstein, R.P. (2006) Association between the Arginine Vasopressin 1a Receptor (AVPR1a) Gene and Autism in a Family-Based Study: Mediation by Socialization Skills. Molecular Psychiatry, 11, 488-494. http://dx.doi.org/10.1038/sj.mp.4001812

[35] Meyer-Lindenberg, A., Kolachana, B., Gold, B., Olsh, A., Nicodemus, K.K., Mattay, V., Dean, M. and Weinberger, D.R. (2009) Genetic Variants in AVPR1A Linked to Autism Predict Amygdala Activation and Personality Traits in Healthy Humans. Molecular Psychiatry, 14, 968-975. http://dx.doi.org/10.1038/mp.2008.54

[36] Levitin, D. and Tirovolas, A.K. (2009) Current Advances in the Cognitive Neuroscience of Music. Annals of the New York Academy of Sciences, 1156, 211-231. http://dx.doi.org/10.1111/j.1749-6632.2009.04417.x

[37] Knafo, A., Israel, S., Darvasi, A., Bachner-Melman, R., Uzefovsky, F., Cohen, L., Feldman, E., Lerer, E., Laiba, E., Raz, Y., Nemanov, L., Gritsenko, I., Dina, C., Agam, G., Dean, B., Bornstein, G. and Ebstein, R.P. (2008) Individual Differences in Allocation of Funds in the Dictator Game Associated with Length of the Arginine Vasopressin 1a Receptor RS3 Promoter Region and Correlation between RS3 Length and Hippocampal mRNA. Genes, Brain and Behavior, 7, $266-275$. http://dx.doi.org/10.1111/j.1601-183X.2007.00341.x

[38] Thompson, R., Gupta, S., Miller, K., Mills, S. and Orr, S. (2004) The Effects of Vasopressin on Human Facial Responses Related to Social Communication. Psychoneuroendocrinology, 29, 35-48. http://dx.doi.org/10.1016/S0306-4530(02)00133-6

[39] Walum, H., Westberg, L., Henningsson, S., Neiderhiser, J.M., Reiss, D., Igl, W., Ganiban, J.M., Spotts, E.L., Pedersen, N.L., Eriksson, E. and Lichtenstein, P. (2008) Genetic Variation in the Vasopressin Receptor 1a Gene (AVPR1A) Associates with Pair-Bonding Behavior in Humans. Proceedings of the National Academy of Sciences of the United States of America, 105, 14153-14156. http://dx.doi.org/10.1073/pnas.0803081105

[40] Hammock, E.A.D. and Young, L.J. (2006) Oxytocin, Vasopressin and Pair Bonding: Implications for Autism. Philosophical Transactions of the Royal Society of London. Series B: Biological Sciences, 361, 2187-2198. http://dx.doi.org/10.1098/rstb.2006.1939

[41] Zeki, S. (2007) The Neurobiology of Love. FEBS Letters, 581, 2575-2579. http://dx.doi.org/10.1016/j.febslet.2007.03.094

[42] Canli, T. and Lesch, K.P. (2007) Long Story Short: The Serotonin Transporter in Emotion Regulation and Social Cognition. Nature Neuroscience, 10, 1103-1109. http://dx.doi.org/10.1038/nn1964

[43] Wendland, J.R., Martin, B.J., Kruse, M.R., Lesch, K.P. and Murphy, D.L. (2006) Simultaneous Genotyping of Four Functional Loci of Human SLC6A4, with a Reappraisal of 5-HTTLPR and rs25531. Molecular Psychiatry, 11, $224-226$. http://dx.doi.org/10.1038/sj.mp.4001789

[44] Hu, X., Oroszi, G., Chun, J., Smith, T.L., Goldman, D. and Schuckit, M.A. (2005) An Expanded Evaluation of the Relationship of Four Alleles to the Level of Response to Alcohol and Alcholism Risk. Alcoholism: Clinical and Experimental Research, 29, 8-16. http://dx.doi.org/10.1097/01.ALC.0000150008.68473.62

[45] Donaldson, Z.R., Kondrashov, F.A., Putnam, A., Bai, Y., Stoinski, T.L., Hammock, E.A. and Young, L.J. (2008) Evolution of a Behavior-Linked Microsatellite-Containing Element of the 5' Flanking Region of the Primate AVPR1A Gene. BMC Evolutionary Biology, 8, 180-188. http://dx.doi.org/10.1186/1471-2148-8-180

[46] Samuvel, D.J., Jayanthi, L.D., Bhat, N.R. and Ramamoorthy, S. (2005) A Role for p38 Mitogen-Activated Protein Kinase in the Regulation of the Serotonin Transporter: Evidence for Distinct Cellular Mechanisms Involved in Transporter Surface Expression. The Journal of Neuroscience, 25, 29-41. http://dx.doi.org/10.1523/JNEUROSCI.3754-04.2005

[47] Quick, M.W. (2003) Regulating the Conducting States of a Mammalian Serotonin Transporter. Neuron, 40, $537-549$. http://dx.doi.org/10.1016/S0896-6273(03)00605-6

[48] Quick, M.W. (2002) Role of Syntaxin 1A on Serotonin Transporter Expression in Developing Thalamocortical Neurons. International Journal of Developmental Neuroscience, 20, 219-224. http://dx.doi.org/10.1016/S0736-5748(02)00021-7

[49] Haase, J., Killian, A.M., Magnani, F. and Williams, C. (2001) Regulation of the Serotonin Transporter by Interacting 
Proteins. Biochemical Society Transactions, 29, 722-728. http://dx.doi.org/10.1042/BST0290722

[50] Curran, M.E., Atkinson, D.L., Ewart, A.K., Morris, C.A., Leppert, M.F. and Keating, M.T. (1993) The Elastin Gene Is Disrupted by a Translocation Associated with Supravalvular Aortic Stenosis. Cell, 73, 159-168. http://dx.doi.org/10.1016/0092-8674(93)90168-P

[51] Schubert, C. (2009) The Genomic Basis of the Williams-Beuren Syndrome. Cellular and Molecular Life Sciences, 66, 1178-1197. http://dx.doi.org/10.1007/s00018-008-8401-y

[52] Enkhmandakh, B., Makeyev, A.V., Erdenechimeg, L., Ruddle, F.H., Chimge, N.O., Tussie-Luna, M.I., Roy, A.L. and Bayarsaihan, D. (2009) Essential Functions of the Williams Syndrome-Associated TFII-I Genes in Embryonic Development. Proceedings of the National Academy of Sciences of the United States of America, 106, 181-186. http://dx.doi.org/10.1073/pnas.0811531106

[53] Edelmann, L., Prosnitz, A., Pardo, S., Bhatt, J., Cohen, N., Lauriat, T., Ouchanov, L., González, P.J., Manghi, E.R., Bondy, P., Esquivel, M., Monge, S., Delgado, M.F., Splendore, A., Francke, U., Burton, B.K. and McInnes, L.A. (2007) An Atypical Deletion of the Williams Syndrome Interval Implicates Genes Associated with Defective Visuospatial Processing and Autism. Journal of Medical Genetics, 44, 136-143. http://dx.doi.org/10.1136/jmg.2006.044537

[54] Hoogenraad, C.C., Koekkoek, B., Akhmanova, A., Krugers, H., Dortland, B., Miedema, M., van Alphen, A., Kistler, W.M., Jaegle, M., Koutsourakis, M., Van Camp, N., Verhoye, M., van der Linden, A., Kaverina, I., Grosveld, F., De Zeeuw, C.I. and Galjart, N. (2002) Targeted Mutation of Cyln2 in the Williams Syndrome Critical Region Links CLIP115 Haploinsufficiency to Neurodevelopmental Abnormalities in Mice. Nature Genetics, 32, 116-127. http://dx.doi.org/10.1038/ng954

[55] Merla, G., Howald, C. and Antonarakis, S.E. (2004) The Subcellular Localization of the ChoRE-Binding Protein, Encoded by the Williams-Beuren Syndrome Critical Region Gene 14, Is Regulated by 14-3-3. Human Molecular Genetics, 13, 1505-1514. http://dx.doi.org/10.1093/hmg/ddh163

[56] Burgess, S.C., Iizuka, K., Jeoung, N.H., Harris, R.A., Kashiwaya, Y., Veech, R.L., Kitazume, T. and Uyeda, K. (2008) Carbohydrate-Response Element-Binding Protein Deletion Alters Substrate Utilization Producing an Energy-Deficient Liver. Journal of Biological Chemistry, 283, 1670-1678. http://dx.doi.org/10.1074/jbc.M706540200

[57] Cherniske, E.M., Carpenter, T.O., Klaiman, C., Young, E., Bregman, J., Insogna, K., Schultz, R.T. and Pober, B.R. (2004) Multisystem Study of 20 Older Adults with Williams Syndrome. American Journal of Human Genetics, 131, 255-264. http://dx.doi.org/10.1002/ajmg.a.30400

[58] Merla, G., Brunetti-Pierri, N., Micale, L. and Fusco, C. (2010) Copy Number Variants at Williams-Beuren Syndrome 7q11.23 Region. Human Genetics, 128, 3-26. http://dx.doi.org/10.1007/s00439-010-0827-2

[59] Buznikov, G.A. and Shmukler, Y.B. (1981) Possible Role of "Prenervous” Neurotransmitters in Cellular Interactions of Early Embryogenesis: A Hypothesis. Neurochemical Research, 6, 55-68. http://dx.doi.org/10.1007/BF00963906

[60] Lauder, J.M. (1993) Neurotransmitters as Growth Regulatory Signals: Role of Receptors and Second Messengers. Trends in Neurosciences, 16, 233-239. http://dx.doi.org/10.1016/0166-2236(93)90162-F

[61] Bennett-Clarke, C.A., Leslie, M.J., Lane, R.D. and Rhoades, R.W. (1994) Effect of Serotonin Depletion on VibrissaRelated Patterns of Thalamic Afferents in the Rat's Somatosensory Cortex. Journal of Neuroscience, 14, 7594-7607.

[62] Mazer, C., Muneyyirci, J., Taheny, K., Raio, N., Borella, A. and Whitaker-Azmitia, P. (1997) Serotonin Depletion during Synaptogenesis Leads to Decreased Synaptic Density and Learning Deficits in the Adult Rat: A Possible Model of Neurodevelopmental Disorders with Cognitive Deficits. Brain Research, 760, 68-73. http://dx.doi.org/10.1016/S0006-8993(97)00297-7

[63] Kojic, L., Gu, Q., Douglas, R.M. and Cynader, M.S. (1997) Serotonin Facilitates Synaptic Plasticity in Kitten Visual Cortex: An in Vitro Study. Developmental Brain Research, 101, 299-304. http://dx.doi.org/10.1016/S0165-3806(97)00083-7

[64] Edagawa, Y., Saito, H. and Abe, K. (2001) Endogenous Serotonin Contributes to a Developmental Decrease in LongTerm Potentiation in the Rat Visual Cortex. Journal of Neuroscience, 21, 1532-1537.

[65] Rhoades, R.W., Bennett-Clarke, C.A., Shi, M.Y. and Mooney, R.D. (1994) Effects of 5-HT on Thalamocortical Synaptic Transmission in the Developing Rat. Journal of Neurophysiology, 72, 2438-2450.

[66] Borella, A., Bindra, M. and Whitaker-Azmitia, P.M. (1997) Role of the 5-HT1A Receptor in Development of the Neonatal Rat Brain: Preliminary Behavioral Studies. Neuropharmacology, 36, 445-450. http://dx.doi.org/10.1016/S0028-3908(97)00056-7

[67] Breese, G.R., Vogel, R.A. and Mueller, R.A. (1978) Biochemical and Behavioral Alterations in Developing Rats Treated with 5,7-Dihydroxytryptamine. Journal of Pharmacology and Experimental Therapeutics, 205, 587-595.

[68] Tricklebank, M.D. (1985) The Behavioral Response to 5-HT Receptor Agonists and Subtypes of the Central 5-HT Receptor. Trends in Pharmacological Sciences, 3, 403-407. http://dx.doi.org/10.1016/0165-6147(85)90191-9

[69] Buwalda, B., Nyakas, C., Vosselman, H.J. and Luiten, P.G. (1995) Effects of Early Postnatal Anoxia on Adult Learning and Emotion in Rats. Behavioural Brain Research, 67, 85-90. http://dx.doi.org/10.1016/0166-4328(94)00108-R 
[70] Nyakas, C., Nuwalda, B., Kramers, R.K.J., Traber, J. and Luiten, P.G. (1994) Postnatal Development of Hippocampal and Neocortical Cholinergic and Serotonergic Innervation in Rat: Effects of Nitrite-Induced Prenatal Hypoxia and Nimodipine Treatment. Neuroscience, 39, 541-559. http://dx.doi.org/10.1016/0306-4522(94)90176-7

[71] Whitaker-Azmitia, P.M., Borella, A. and Raio, N. (1995) Serotonin Depletion in the Adult Rat Causes Loss of Dendritic Marker MAP-2. A New Animal Model of Schizophrenia? Neuropharmacology, 12, 269-272.

[72] Blue, M.E., Erzurumlu, R.S. and Jhaveri, S. (1991) A Comparison of Pattern Formation by Thalamocortical and Serotonergic Afferents in the Rat Barrel Field Cortex. Cerebral Cortex, 1, 380-389. http://dx.doi.org/10.1093/cercor/1.5.380

[73] Cases, O., Vitalis, T., Seif, I., De Maeyer, E., Sotelo, C. and Gaspar, P. (1996) Lack of Barrels in the Somatosensory Cortex of Monoamine Oxidase A Deficient Mice: Role of Serotonin Excess during the Critical Period. Neuron, 16, $297-307$. http://dx.doi.org/10.1016/S0896-6273(00)80048-3

[74] Upton, D. and Thompson, P.J. (1999) Twenty Questions Task and Frontal Lobe Dysfunction. Archives of Clinical Neuropsychology, 14, 203-216. http://dx.doi.org/10.1016/S0887-6177(98)00013-4

[75] Salichon, N., Gaspar, P., Upton, A.L., Picaud, S., Hanoun, N., Hamon, M., De Maeyer, E., Murphy, D.L., Mossner, R., Lesch, K.P., Hen, R. and Seif, I. (2001) Excessive Activation of Serotonin (5-HT) 1B Receptors Disrupts the Formation of Sensory Maps in Monoamine Oxidase a and 5-HT Transporter Knock-Out Mice. Journal of Neuroscience, 21, 884-896. 